\title{
The Introduction of Use of Statistics in Education (I-Use): The Case of Use of Statistics in the Geography Curriculum
}

\author{
Luc ZWARTJES ${ }^{1}$, Karl DONERT ${ }^{2}$ and Aikaterina KLONARI ${ }^{3}$ \\ ${ }^{1}$ Ghent University, Belgium·luc.zwartjes@ugent.be \\ ${ }^{2}$ EUROGEO, Belgium \\ ${ }^{3}$ University of the Aegean, Greece
}

This contribution was double-blind reviewed as full paper.

\begin{abstract}
Statistical literacy is gaining increasing importance in everyday life. Almost every economic and scientific activity in the modern world relies on statistical information in one way or another. Students are now living in a society that demands evidence-based arguments and decisions. There are a number of challenges facing education in the use of statistics and data: i) the volumes of information available, ii) the slow response of education and curricula to change, iii) the need for innovative teaching and learning approaches, and iv) the absence of significant research in European statistical education. The I-Use consortium investigated the use of statistics in the geography curricula of the participating countries. Statistics appear mostly in the curricula of mathematics (where it is a separate item) and in geography, although the statistics as a source for real investigation is mostly denied. To help implementing statistics in education, I-Use will create an in-service teacher training course that will deal with how to make sense of information through different presentation forms and media.
\end{abstract}

\section{Defining Statistics}

For the I-Use project the term statistics refers to the branch of scientific methods, that deal with the study of the theory and practice of data collection, data description and analysis, and the making of statistical inferences. Statistics education refers to the art of teaching and learning from these statistical activities from practical and theoretical perspectives. In this definition, data collection is taken to encompass both the design and execution of data collection activities and data editing; the term data description refers to summarising data by qualitative and quantitative measures. Data analysis refers to exploring data tables, trends, and shapes, as well as statistical modelling; statistical inference refers to point and interval estimation and hypothesis testing, and decision theory in so far as that the latter deals with the set of actions or decisions open to the statistician (KLONARI \& DONERT 2013). 


\section{The Importance of Being Statistical Literate}

Statistics - as the science of collecting, analysing, and interpreting empirical data - has a central place in education, but certainly in STEM education. Education concerning the use of statistical information is appropriate for lifelong learners at different levels of education. The relevant use of statistics in education is through its multi-disciplinarity, with its roots in such diverse fields as biology, business studies, economics, environment, ICT, mathematics and social studies (BICKEL 1995). Therefore, statistical literacy should be a key educational goal for all students.

Teaching using statistics requires a different kind of thinking, because data is not just a series of numbers, they are numbers with a context. WILD \& PFANNKUCH (1999) highlighted ways in which statistical thinking is different from mathematical thinking, having investigative cycles, distinctive types of thinking, interrogative cycles, and characteristic dispositions. Students are living in a society that demands evidence-based arguments and decisions. Therefore using statistics in the curriculum plays a crucial role in developing statistical thought processes. Statistical thinking or reasoning or literacy needs to be recognised as an important educational goal and the use of statistics needs to be valued in different disciplines to develop students' statistical concepts and thinking.

\section{The Present Situation on the Use of Statistics in the Curriculum}

One of the first tasks of the I-Use project was to analyse the present situation on the use of statistics in education, namely how Statistics are used in various official national curricula. For the report I-Use mapped the references to "Statistics" in Social Studies, Mathematics and Science secondary school curricula in use in public secondary schools in Flanders (Belgium), Greece, Denmark, Czech Republic and Sweden, at the time of the study (20122013).

The choice of these subjects was underpinned by theoretical lenses drawn from curriculum studies, looking at official curricula as planned learning curriculum. According to these within official curricula, subject-areas such as Mathematics, Geography, History, Civics (Social Studies), Economics/Business Studies, ICT and Sciences have been perceived as more relevant to the use and inclusion of statistics (BICKEL 1995). The result of a quantitative analysis (see Table 1) shows that most references occur in the subjects of Mathematics

\begin{tabular}{|c|c|c|c|c|c|c|c|}
\hline Subject & $\begin{array}{l}\text { Maths \& } \\
\text { Statistics }\end{array}$ & History & $\begin{array}{l}\text { Science } \\
\text { (Physics, } \\
\text { Chemistry, } \\
\text { Biology) }\end{array}$ & Geography & $\begin{array}{l}\text { Social Science } \\
\text { (Civics, } \\
\text { Sociology) }\end{array}$ & Economics & Total \\
\hline $\begin{array}{l}\text { Belgium } \\
\text { (Flemish) }\end{array}$ & 20 & 2 & 10 & 14 & - & - & 46 \\
\hline Denmark & 26 & 1 & 5 & 5 & 14 & - & 51 \\
\hline Sweden & 9 & 1 & 1 & 3 & 1 & - & 15 \\
\hline $\begin{array}{l}\text { International } \\
\text { Baccalaureate }\end{array}$ & 26 & 1 & 6 & 6 & 2 & - & 41 \\
\hline Greece & 76 & 28 & 12 & 74 & 14 & 66 & 270 \\
\hline Czech & 10 & - & - & 5 & 3 & - & 18 \\
\hline Total & 167 & 33 & 34 & 107 & 34 & 66 & 451 \\
\hline
\end{tabular}

Tab. 1:

Mapping 'Statistics' across Europe: overall quantitative content analysis results 
and Geography and comparatively fewer references occurred in History / Civics or Science, a finding relevant to the literature review on this issue.

There is also a great diversity of frequency of statistical use across countries and subjects. In most countries, most references occur in the Mathematics curricula documents, the second highest frequency was encountered in the subject of Geography. Besides the quantitative overview also a qualitative analysis was conducted, indicating that low or high counts in the terms in focus did not necessarily mean the absence or presence of statistics content. As a result of analysing quantitative and qualitative data, the report (KLONARI \& DONERT 2013) clearly remarks that the presence of statistics takes three forms:

1) Pure statistics and probabilities in mathematics, emphasized in mathematical theory, where the key concepts/phrases or activities for exemplifying this theory were apparent, enhancing students' knowledge skills on problem solving (using mathematical theory and data from this topic), but not to promote interplay between theory and application for the real life, nor to prepare students for dealing with contextual problems.

2) Apparent in the data collection, visualisation and interpretation using tables, charts/ diagrams and maps to solve problems in the real world. In this case there is an indirect reference to the use of statistics, but there is a wide occurrence of such references mainly in other subjects' curricula besides mathematics, especially in the geography curriculum.

3) The use of statistics in research or field studies in everyday life, for the development of statistically literate and professional competent people. This is e.g. apparent in the curricula of geography, history, social sciences and economy (Greece).

\section{Challenges Faced}

There are a number of challenges facing education in the use of statistics and data. These include i) the volumes of information available, ii) the slow response of education and curricula to change, iii) the need for innovative teaching and learning approaches and iv) the absence of significant research in European statistical education.

The over-abundance of information poses serious questions, for example what degree of statistical literacy should we expect for every pupil? How can we structure opportunities to enable students to reach this level and to ensure that teachers have sufficient skills to be able to use statistics to improve their teaching? The dilemma is that as more data and information becomes more readily available and the tools for presenting and analysing the statistics become more sophisticated, the ability to introduce and integrate statistical information and undertake analyses is not matched by educators' capacity to use the information, tools and technologies productively.

While the world is changing rapidly with respect to the prevalence and use of statistics, the curriculum in schools tends to be slow to respond to these changes. Although statistics as a content domain is widely accepted, typically statistics is not an interdisciplinary topic in the school curriculum, but is mainly taught as part of mathematics and rarely integrated into other subject areas. Consequently there is a need for a better preparation of teachers, who are responsible for teaching with statistics. As a result in high school, many students do not have an opportunity to learn to work with statistics. Statistics is a powerful tool but many students are not able to make sense of the data and information. 


\section{$5 \quad$ Identified Problems in Teaching and Learning Using Statistics}

The I-Use project reviewed the literature related to statistics pedagogy and summarised the recommendations and techniques which can be potentially useful in teaching and learning statistics with special focus on strategies to promote statistical literacy and motivate students to learn statistics.

Tab. 2: List of Identified Problems in Teaching Statistics

\begin{tabular}{|l|l|}
\hline Author & Identified Problems \\
\hline GARFIELD (1995) & $\begin{array}{l}\text { Focus on mathematical and mechanical aspects of knowl- } \\
\text { edge. It results in students not being empowered to apply } \\
\text { these aspects of statistical knowledge to solve problems } \\
\text { generally arising from a specific context. }\end{array}$ \\
\hline GARFIELD (1995), VERHOEVEN (2006) & 'Maths-phobia', 'statistics anxiety' and lack of interest. \\
\hline $\begin{array}{l}\text { GARFIELD (1995), GARFIELD \& } \\
\text { BEN-ZVI (2002) }\end{array}$ & $\begin{array}{l}\text { Ideas of probability and statistics are very difficult for stu- } \\
\text { dents to learn. }\end{array}$ \\
\hline GARFIELD AND AHLGREN (1988) & Deficiencies in basic statistical knowledge. \\
\hline VERHOEVEN (2006) & $\begin{array}{l}\text { Statistics courses are given as 'service teaching' with no link } \\
\text { to subject area. }\end{array}$ \\
\hline $\begin{array}{l}\text { GAL (2002), SCHIELD (2004), } \\
\text { VERHOEVEN (2006) }\end{array}$ & $\begin{array}{l}\text { Lack of statistical literacy and inability of students in using } \\
\text { statistics in every day life. }\end{array}$ \\
\hline WATSON (1997/2013), GAL (2002) & $\begin{array}{l}\text { Deficiency in tools to assess statistical thinking and statisti- } \\
\text { cal literacy of population in the social settings. }\end{array}$ \\
\hline BATANERO \& DIAZ (2010) & $\begin{array}{l}\text { Teachers have static view of the way that statistics can and } \\
\text { should used in class. }\end{array}$ \\
\hline ROBERTS' REVIEW (2002) & Shortage of statisticians in the workplace. \\
\hline
\end{tabular}

One of the implications of the problems summarised in Table 2 was a movement to socially-based curriculum frameworks and towards applications-based approaches to teaching students to think critically about social situations in which data are used, sometimes referred to as applying statistical literacy.

\section{Review of Recommendations and Suggested Strategies}

If we want to improve the teaching of statistics we need to adopt changes implementing students to receive training that is both up-to-date and relevant for society's needs. Table 3 provides a list of some reform-based strategies and techniques, brief descriptions and examples of how they are used. 
Tab. 3: Overview of Reform-Based Learning Strategies and Techniques (after TISHKOVSKAYA \& LANCASTER 2010 / 2012)

\begin{tabular}{|c|c|}
\hline Suggested Strategy & Examples of Use \\
\hline $\begin{array}{l}\text { Integrating schemes for assessment of statis- } \\
\text { tical thinking and statistical literacy in to the } \\
\text { curriculum (GAL 2002, SCHIELD 2004, } \\
\text { WATSON 1997) }\end{array}$ & $\begin{array}{l}\text { Using media reports and newspaper articles to assess } \\
\text { the students' ability of interpretive statistical think- } \\
\text { ing. }\end{array}$ \\
\hline $\begin{array}{l}\text { Shifting the focus of statistics curricula from } \\
\text { mathematical calculations to tasks of practi- } \\
\text { cal nature (CHANCE 1997) }\end{array}$ & $\begin{array}{l}\text { Students are given problems within different con- } \\
\text { texts so they exercise what they have learned in a } \\
\text { variety of ways. Consider real world examples and } \\
\text { applications. }\end{array}$ \\
\hline $\begin{array}{l}\text { Developing problem solving skills } \\
\text { (GARFIELD 1993/1995, MARRIOTT et al. } \\
\text { 2009) }\end{array}$ & $\begin{array}{l}\text { Implement problem-based learning strategies giving } \\
\text { students open-ended problems and taking the role of } \\
\text { 'facilitator' in the learning process. Use of real life } \\
\text { examples in project work. }\end{array}$ \\
\hline $\begin{array}{l}\text { Developing strategies to motivate students } \\
\text { (GARFIELD 1993, WATSON 1997) }\end{array}$ & $\begin{array}{l}\text { Provide examples that have recently appeared in the } \\
\text { media, government reports, news. }\end{array}$ \\
\hline $\begin{array}{l}\text { Developing statistical literacy and critical } \\
\text { thinking skills. (WALLMAN 1993, GAL 2002, } \\
\text { SCHIELD 2004, ARNOLD 2008) }\end{array}$ & $\begin{array}{l}\text { Include statistical literacy component in the statisti- } \\
\text { cal course; Focus on everyday arguments that use } \\
\text { statistics as evidence; Use examples of incorrect } \\
\text { analyses. }\end{array}$ \\
\hline $\begin{array}{l}\text { Collaborative learning. (GARFIELD } 1993 \text { / } \\
\text { 1995) }\end{array}$ & $\begin{array}{l}\text { Students work together to solve problems or discuss } \\
\text { concepts, sharing ideas and understanding; Collabo- } \\
\text { rative group work with computers. }\end{array}$ \\
\hline $\begin{array}{l}\text { Active learning and introducing activities } \\
\text { where students are able to construct knowl- } \\
\text { edge (GARFIELD 1993) }\end{array}$ & $\begin{array}{l}\text { Students are engaged in data collection, reflection on } \\
\text { and exploration of statistical concepts, and solving } \\
\text { problems on their own. Small-group cooperative } \\
\text { learning (as one of the ways for teachers to incorpo- } \\
\text { rate active learning) }\end{array}$ \\
\hline $\begin{array}{l}\text { Emphasis on exploration PFANNKUCH \& BEN } \\
\text { ZVI 2011) }\end{array}$ & $\begin{array}{l}\text { Students posing their own questions, interrogating } \\
\text { the data and learning new information about the real } \\
\text { world. }\end{array}$ \\
\hline $\begin{array}{l}\text { Target misconceptions through discussion } \\
\text { and assessment. (CHANCE 1997, GARFIELD } \\
\text { 1995) }\end{array}$ & $\begin{array}{l}\text { Instructions designed so that students will be encour- } \\
\text { aged to discuss their misconceptions; Introduce } \\
\text { interactive assignments with feedback. }\end{array}$ \\
\hline $\begin{array}{l}\text { Developing the skill of communicating } \\
\text { statistics (SCHIELD 2004) }\end{array}$ & $\begin{array}{l}\text { Translate and present complex concepts into a format } \\
\text { understandable to a wide audience; Ask students to } \\
\text { explain terminology and to interpret the statistical } \\
\text { results in everyday words }\end{array}$ \\
\hline $\begin{array}{l}\text { Use of TPCK model (BATANERO et al. 2011, } \\
\text { LEE, HOLLEBRANDS \& WILSON 2010) }\end{array}$ & $\begin{array}{l}\text { Using a model of technological and pedagogical } \\
\text { content knowledge that takes into account the statis- } \\
\text { tical reasoning and concerns the pedagogical exper- } \\
\text { tise for the effective engaging of students in learning } \\
\text { with technologies }\end{array}$ \\
\hline $\begin{array}{l}\text { Use of technology and on-line resources } \\
\text { (GARFIELD 1995, Mills 2002, LEE \& } \\
\text { HoLLEBRANDS 2008) }\end{array}$ & $\begin{array}{l}\text { Presentation of new material with the use of statisti- } \\
\text { cal software Simulation programs which allow stu- } \\
\text { dents to explore statistical concepts in discovery- } \\
\text { world environments Using useful resources available } \\
\text { online. }\end{array}$ \\
\hline
\end{tabular}




\section{Recommendations}

As a summary in the reports on the pedagogic approaches to statistics use and on the pedagogic importance of statistics (KLONARI \& DONERT 2013b) the following recommendations were made.

A course for secondary school teachers requires a focus on curriculum to make a clear connection between the statistics presented and the subject under study in a school classroom. A focus on pedagogy is needed so that teachers learn to regularly adopt the use of statistics in their own classrooms and develop similar types of activities for their students to experience. A focus on learners is required so that teachers understand the diversity of statistical perceptions and misunderstandings of students.

Working with new technology helps to engage teachers and students in tasks that simultaneously develop their understanding of statistical ideas and allows them to experience how technology tools can be useful in fostering statistical and spatial thinking (LEE \& HOLLEBRANDS 2008).

Stressing problem-solving ensures that the outcomes have a real-world dimension. Ideas should develop in the context of the problem-solving activities using statistics, which encourage the development of statistical reasoning skills so that the use of statistics is a means of supporting learning (BIEHLER et al. 2013, COBB 1999).

The data analysis/interpretation phase requires a thorough understanding of data representations. Different representations of distributions also affect students' understanding of concepts.

Teachers should experience the full cycle of statistical use through enquiry-based projects. GoDINO et al. (2008/2011) suggested that a formative cycle where teachers are first given a statistical project and then carry out a didactical analysis of the project can help to simultaneously increase the teachers' statistical and pedagogical knowledge

\section{I-Use Deliverables}

Taking into account these recommendations the I-Use project deals with data, statistics and pedagogical approaches, applying them to various areas in the secondary school curricula. The three year I-Use Comenius Project aims to:

- help cope with the over-abundance information-rich resources

- encourage teachers to engage their students in learning to use and work with statistics

- make statistical education more visible under the Life Long Learning Program

- prepare teachers for the technology-mediated nature of working with statistical information

- keep up with Web-based innovation

- develop teachers' statistical competence

- provide training for teachers of different subjects

After one year, the project is currently busy with developing material for its website (www.i-use.eu). 
The project has already developed an interactive toolbox, fully integrated with the web site and based on the surveyed needs of students and teachers. The tools will make full use of mobile devices (like tablets) and (web)GIS, as it is a simple yet powerful method of visualizing statistical investigation, not only in geography. With the use of this toolbox teachers will be able to work interactively with statistical data, visualizing it in both space and time in an innovative way.

The final and major goal is to create an in-service teacher training course dealing with how to make sense of information through different presentation forms and media. This will explore various methods of using statistical data within an educational context. There will be a cross-curricular approach: the course will be useful for teachers who have specialised in more than one subject, from social studies over geography to economy, history. A first pilot of this course will take place in Greece in September 2014. Trainees will examine how to develop students' statistical thinking through sophisticated and innovative webbased tools to support the learning process.

I-Use will also deal with the assessment of student learning, making the distinction between assessment of learning (summative) and assessment for learning (formative) approaches. This will be addressed through three basic components, namely, cognition, observation and interpretation that underlie all forms of evaluation.

\section{The INSPIRE Directive, an Opportunity for Geography to Promote the Use of Statistics Using geo-ICT}

Using statistics in education in Europe should specifically draw on developments made under the European INSPIRE Directive on data transferability. The INSPIRE Directive, initiated in May 2007, is establishing an infrastructure for spatial information in Europe, predominantly to support EC policies and activities which may have an impact on the environment (EUROPEAN COMMISSION 2013). INSPIRE is based on the infrastructures for spatial information established and operated by the 27 Member States of the European Union. The Directive addresses 34 spatial data themes needed for environmental applications, with key components specified through technical implementing rules.

INSPIRE is based on a number of common principles:

- Data should be collected only once and kept where it can be maintained most effectively.

- It should be possible to combine seamless spatial information from different sources across Europe and share it with many users and applications.

- It should be possible for information collected at one level/scale to be shared with all levels/scales; detailed for thorough investigations, general for strategic purposes.

- Geographic information needed for good governance at all levels should be readily and transparently available.

- It should be easy to find what geographic information is available, how it can be used to meet a particular need, and under which conditions it can be acquired and used.

The data for INSPIRE is gathered by national statistical agencies using defined protocols and metadata. In many countries, the statistical offices and agencies will be able to provide 
resources that can be used to support the introduction of statistical literacy in schools. However, without wide-reaching education and professional development of teachers, such resources are unlikely to have an impact on students. Moreover, in order for teachers to develop a deep and meaningful understanding of statistics that they can later use to help students develop the ability to think and reason statistically, it is important to create a statistical reasoning learning environment in the courses they take (GARFIELD \& BEN-ZVI 2009).

If we also take into consideration the recommendation to work with new technology in problem-solving activities, it is obvious to see the use of GIS as the perfect tool to promote statistics on geography education. Although using the more 'traditional' methods can also be very efficient.

Take for example the use of tables and graphs in geography school textbooks. In older textbooks tables and graphs where just used to illustrate what is written in the text, they were not used as investigation tool (see Figure 1).

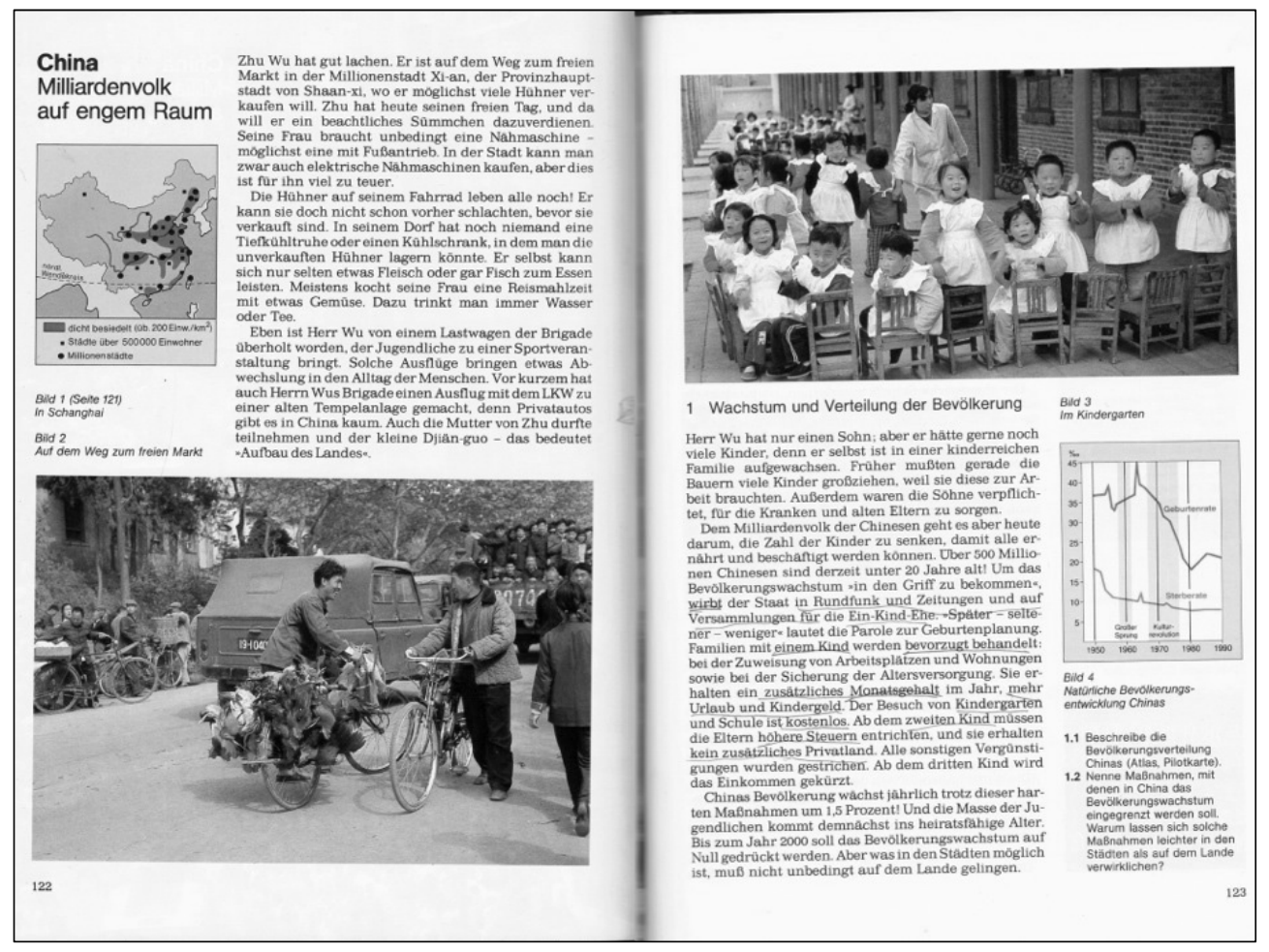

Fig. 1: Population study of China in a typical 1980's schoolbook (Diercke Erdkunde für Gymnasien in NRW, Industriestaaten und Entwicklungsländer, 8, 1986)

In most existing schoolbooks the methods pupils are asked to use are mainly to analyse and interpret data and graphs. In this example, using the same subject (population) pupils need to combine the information they derive from the table with the graphs and their own analysis (see Figure 2). 
3.7 Ontwikkelingslanden versus industrielanden: een eigen demografisch onderzoek

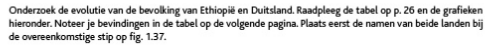
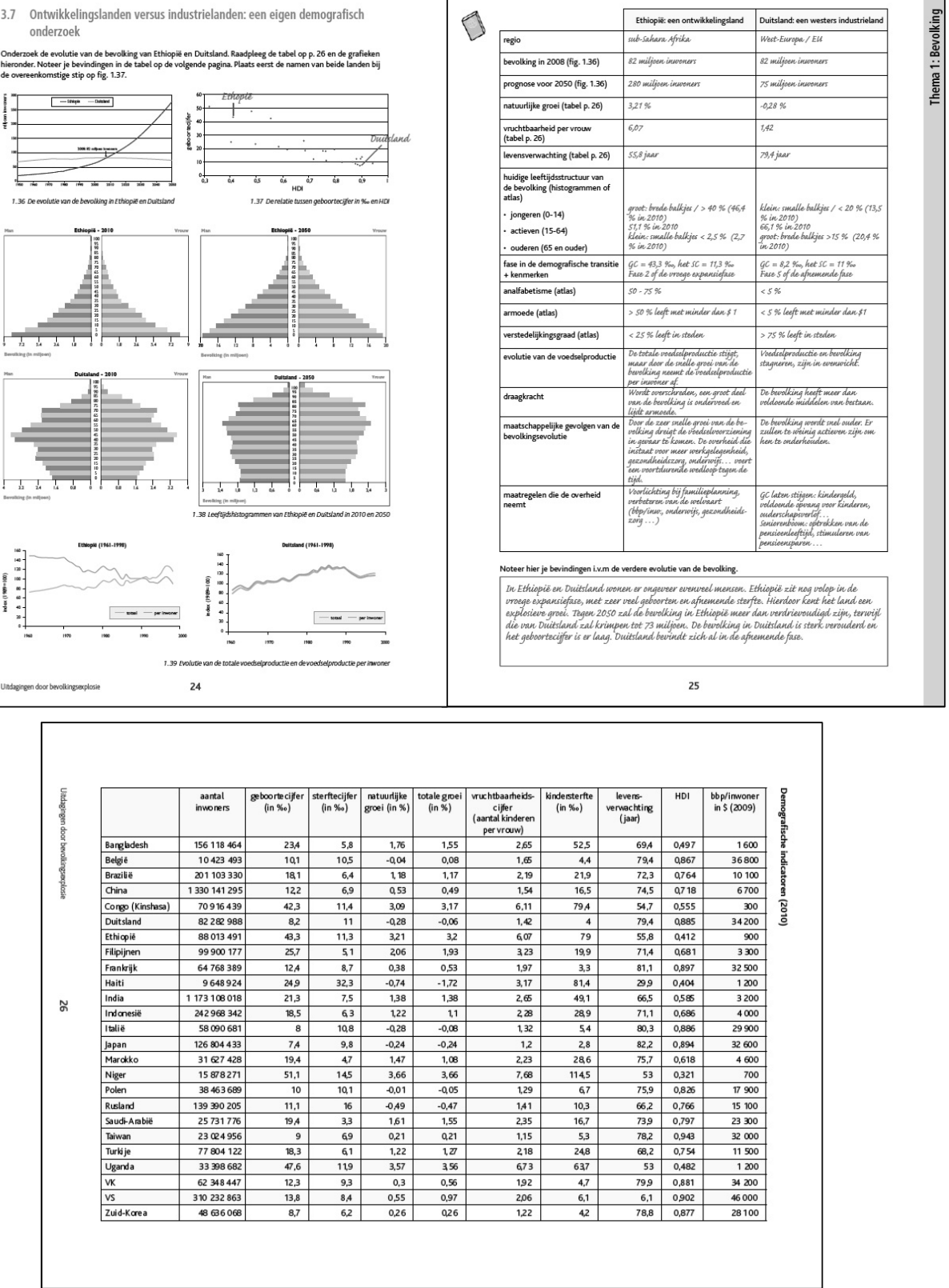

Fig: 2: Comparative study of the characteristics of the population in a typical 2010's school workbook (Geogenie 4, editor De Boeck 2013).

But it is obvious that by using geo-ICT tools like (web)GIS (see Figure 3), more complex and challenging investigations can be done of their own environment, using real-time data 
available via the INSPIRE Directive, thus adding a real-world dimension to exercises and activities. Learners can be challenged for example to think about the significance of spatial decisions, in fact educating them for (spatial) citizenship (GRYL et al. 2010).

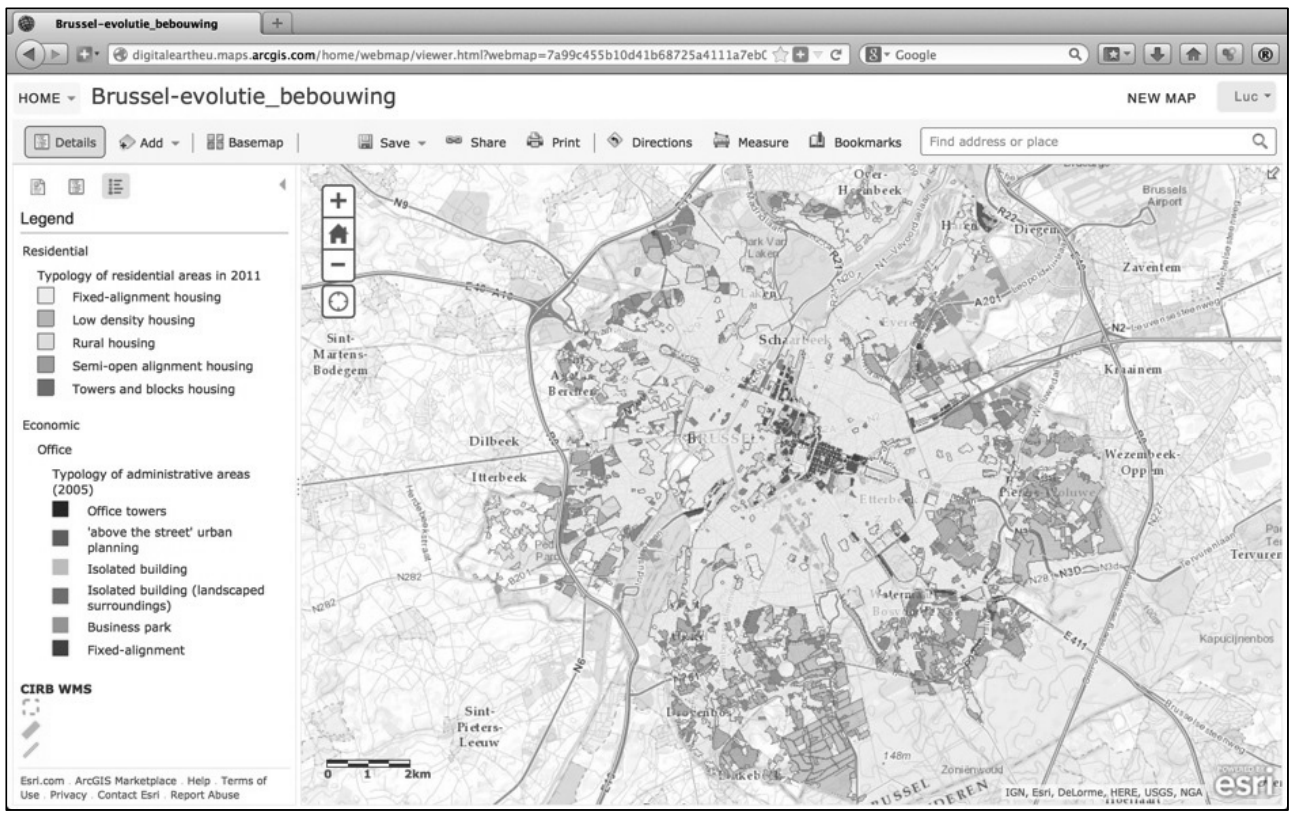

Fig. 3: ArcGIS online Map of Brussels showing the typology of residential and administrative areas

\section{Conclusion and Outlook}

Despite the growing need for data scientists, statistical education in Europe is not a separate subject at either primary or secondary school level. It appears that statistics, when present in the curriculum, is universally included within mathematics. There is a general tendency to teach statistical concepts (in mathematics) at very early ages in many countries; in some, six year-old children start studying basic statistical concepts and continue to develop these concepts in all the curricular levels until secondary school (FURRINGHETTI et al. 2013).

The use of statistics is 'indirectly' introduced in secondary school curricula. Our indications from I-Use the state-of-the-art surveys (DONERT \& KLONARI 2013a/2013b), is that teachers believe that understanding statistics is important for educated citizens, but there is great diversity of opinions about what aspects of statistics should be taught in schools and how they should be taught. Changing traditional approaches and attitudes towards statistics, is however quite difficult. Deep-rooted beliefs about the nature of statistics are based in mathematics as a subject of deterministic and hierarchically-structured knowledge (MAKAR \& CONFREY 2003). Members of the I-Use project believe that perhaps now is an opportunity for geo-statistical education to take the stage if we are to 'unlock the goldmine that is open data' (KROES 2012). 


\section{References}

BAtanero, C. \& DíAZ, C. (2010), Training teachers to teach statistics: what can we learn from research? Statistique et enseignement, 1 (1), 5-20. http://statistique-etenseignement.fr/ojs/.

Batanero, C., Arteaga, P. \& Contrera, J. M. (2011), El currículo de estadística en la enseñanza obligatoria. EM TEIA | Revista de Educação Matemática e Tecnológica Iberoamericana, 2 (2).

BiCKel, P. J. (1995), What academia needs. The American Statistician, 49, 5-6.

BIEHLER, R., BEN-Zvi, D., BAKKER, A. \& MAKAR, K. (2013), 'Technology for enhancing statistical reasoning at the school level'. In: Third International Handbook of Mathematics Education, 27, New York, Springer, 643-689.

ChANCE, B. L. (1997), Experiences with authentic assessment techniques in an introductory statistics course. Journal of Statistics Education, 5 (3), 1-15.

CoBB, P. (1999), Individual and Collective Mathematical Development: The Case of Statistical Data Analysis. Mathematical Thinking and Learning, 1 (1), 5-43.

EUROPEAN COMMISSION (2013), INSPIRE: Infrastructure for Spatial Information in the European Community, JRC. http://inspire.jrc.ec.europa.eu/.

FuringhetTi, F, Matos, J.-M. \& MENGHINI, M. (2013), 'From mathematics and education, to mathematics education'. Third international handbook of mathematics education, New York, Springer, 27, 273-302.

GAL, I. (2002), Adult's statistical literacy. Meanings, components, responsibilities. International Statistical Review, 70 (1), 1-25.

GARFIELD, J. (1993), Teaching statistics using small-group cooperative learning. Journal of Statistics Education, 1 (1), 1-9.

GARFIELD, J. (1995), How students learn statistics. Int. Statistical Review, 63 (1), 25-34.

GARFIELD, J. \& AHLGREN, A. (1988), Difficulties in learning basic concepts in probability and statistics: Implications for research. Journal of Research in Mathematics Education, 19, 44-63.

Garfield, J. \& Ben-Zvi, D. (2002), Developing Students' Statistical Reasoning: Connecting Research and Teaching Practice. Springer.

GARFIELD, J. \& BEN-ZVI, D. (2009), Helping students develop statistical reasoning: Implementing a Statistical Reasoning Learning Environment. Teaching Statistics, 31 (3), $72-77$.

Godino, J. D., BAtanero, C., RoA, R. \& Wilhelmi, M. R. (2008), Assessing and developing pedagogical content and statistical knowledge of primary school teachers through project work. Joint ICMI/IASE study: teaching statistics in school mathematics. Challenges for teaching and teacher education. Proceedings of the ICMI study, 18.

Godino, J. D., Ortiz, J. J., RoA, R., \& Wilhelmi, M. R. (2011), Models for statistical pedagogical knowledge. In Teaching Statistics in School Mathematics-Challenges for Teaching and Teacher Education. Springer, Netherlands, 271-282.

GRYL, I., JEKEL, T. \& DONERT, K. (2010), GI and spatial citizenship. Learning with GI V, 211.

KlONARI, A. \& DONERT, K. (2013a), Report on the present situation on the use of statistics in the curriculum, I-Use Project. http://i-use.eu/publications/curriculum.html (21/4/2014). 
Klonari, A. \& Donert, K. (2013b), Report on the pedagogic importance of statistics, I-Use Project. http://i-use.eu/publications/reports.html (21/4/2014).

KroES, N. (2012), The EU unlocking a goldmine of open data. http://blog.opengovpartnership.org/2012/09/the-eu-unlocking-a-goldmine-of-opendata/.

LeE, H. \& Hollebrands, K. (2008), Preparing to teach mathematics with technology: An integrated approach to developing technological pedagogical content knowledge. Contemporary Issues in Technology and Teacher Education, 8 (4), 326-341.

MAKAR, K. \& CONFREY, J. (2005), 'Using distributions as statistical evidence in wellstructured and ill-structured problems'. In: MAKAR, K. (Ed.), Reasoning about distribution: A collection of current research studies. Proc. Fourth International Research Forum on Statistical Reasoning, Thinking and Literacy (SRTL-4), University of Auckland, New Zealand, 2-7 July. Brisbane: University of Queensland.

MARriotT, J., DAVIES, N. \& GiBSON, L. (2009), Teaching, learning and assessing statistical problem solving. Journal of Statistics Education, 17 (1), 1.

MiLLS, J. D. (2002), Using computer simulation methods to teach statistics: A review of the literature. Journal of Statistics Education, 10 (1), 1-20.

ROBERTS, G. G. (2002), SET for success: the supply of people with science, technology, engineering and mathematics skills: the report of Sir Gareth Roberts' review.

SCHIELD, M. (2004), Information literacy, statistical literacy and data literacy. IASSIST Quarterly, 28 (2/3), 6-11.

TISHKOVSKAYA, S. \& LANCASTER, G. A. (2010), Teaching strategies to promote statistical literacy: review and implementation. In Proceedings of the 8th International Conference on Teaching Statistics, 11-16 July, Ljubljana, Slovenia.

TishKovsKayA, S. \& LANCASTER, G. (2012), Statistical education in the 21st century: a review of challenges, teaching innovations and strategies for reform. Journal of Statistics Education, 20 (2), 1-55.

Verhoeven, P. (2006), Statistics education in the Netherlands and Flanders: An outline of introductory courses at Universities and Colleges. In ICOTS-7 Conference Proceedings, cited in TishKovskaya, S., \& LANCASTER, G. A. (2010), Teaching strategies to promote statistical literacy: review and implementation. In: Proceedings of the 8th International Conference on Teaching Statistics, 11-16 July, Ljubljana, Slovenia.

Watson, J. (1997), Assessing Statistical Thinking Using the Media. In: The Assessment Challenge in Statistics Education, ed. by I. GAL \& J. GARFIELD. Amsterdam, IOS Press and International Statistical Institute.

WATSON, J. M. (2013), Statistical literacy at school: Growth and goals. Routledge.

Wallman, K. K. (1993), Enhancing statistical literacy: Enriching ow society. Journal of the American Statistical Association, 88, 1-8.

Wild, C. J. \& PfannKuCH, M. (1999), Statistical thinking in empirical enquiry. International Statistical Review, 67 (3), 223-248. 